\title{
REGULATIONS OF THE
}

\section{UNIPBD SMATAS GBOLOGICAC SURVEY}

CHARLAS D. WALCOTY DIRECYOR

\section{TEIRD ADITION}

APPROTBD DECDMBER 27, 1902, TO TAKR RPFECT JANOARY 1, 1903 

Dernaroftíne

Ul

\&.

Pune 12,1905

Bequeathed to 



UNITED STATES GEOLOGICAL SURVEY

CHARLES D. WALCOT'T, DIRECTOR

\title{
REGULATIONS
}

OF THE

\section{UNITED STATES GEOLOGICAL SURVEY}

\author{
THIRI FIDITION
}

APPROVED DECEMBER 27, 1902, T0 TAKE EFFECT JANUARY 1, 1903.

WASHINGTON

GOVERNMENT PRINTING OFFICE

- 1903 . 



\section{C $0 \mathrm{~N}$ T E N TS.}

Page.

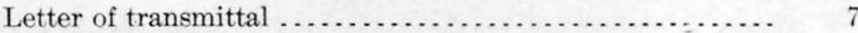

Introduction ................................. 9

Organic and other laws, with instructions relating thereto . 9

1. The organic law .......................... 9

2. Hydrographic and reclamation service........... 10

3. Forest reserves........................... 12

4. Alaska .................................. 14

5. Publications ............................ 14

6. Legal prohibitions ....................... 15

7. Entry upon private property ................. 16

8. Preservation of public monuments ............. $\quad 16$

9. Confidential information ................... 17

10. Expert testimony ......................... 17

11. Private collections ....................... 18

General instructions and office regulations............. 18

12. Organization............................ 18

13. Official correspondence ...................... 19

14. Use of official frank ....................... 19

15. Chief $\operatorname{clerk}$.............................. 20

16. Chief disbursing clerk $\ldots \ldots \ldots \ldots \ldots \ldots \ldots \ldots \ldots .20$

17. Librarian ............................... 20

18. Editor of publications ..................... 21

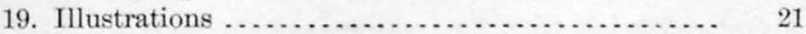

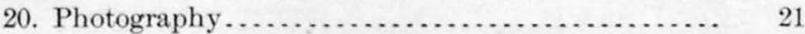

21. Custodian of documents ................... 22

22. Classification of technical force $\ldots \ldots \ldots \ldots \ldots \ldots .22$

23. Transfers from one division or section to another.. 23

24. Leaves of absence ........................ 23 
General instructions and office regulations-Continued.

Page.

25. Employment of field assistants, rodmen, chainmen, flagmen, and laborers.................. 23

26. Importunities for promotion $\ldots \ldots \ldots \ldots \ldots \ldots \ldots .24$

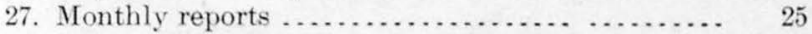

28. Notes and notebooks ..................... 25

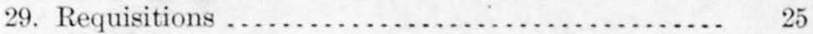

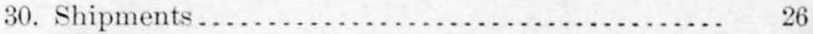

31. Smoking and use of matches............... 26

Duties of disbursing agents . . . . . . . . . . . . . . . . . 26

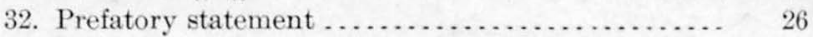

33. Relation to the Government $\ldots \ldots \ldots \ldots \ldots \ldots \ldots .27$

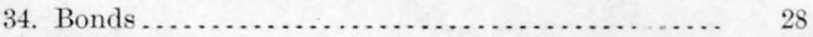

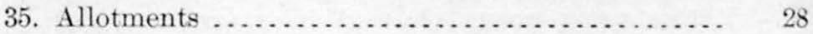

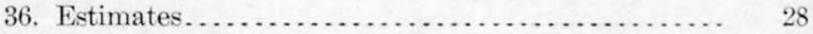

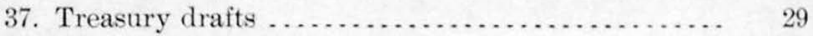

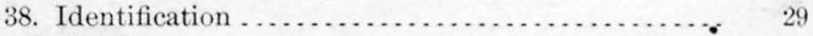

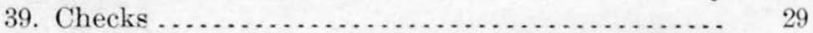

Disbursements. . . . . . . . . . . . . . . . . . . . . . . 30

40. Classification of disbursements ............. 30

41. Rendering of voucher accounts............. 30

42. Vouchers in duplicate ................... 31

43. Disbursements for services .................. 31

44. Vouchers from employees.................. 33

45. Disbursements for traveling expenses .......... 33

46. Fiscal years and quarters ...................... 35

47. Disbursements for purchases and miscellaneous ex-

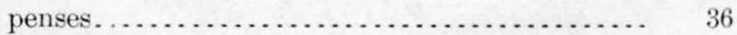

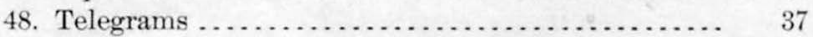

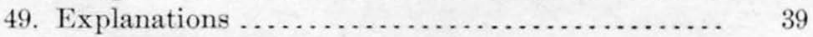

50. Settlement of accounts by mail ............. 39

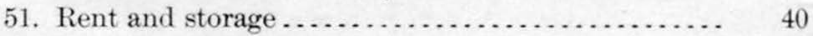

52. Contracts ........................... 40

Property ................................ 40

53. Classification of expenditures .............. 40

54. Nonexpendable property .................. 41

55. Expendable property .................... 43 
Property-Continued.

Page.

56. Custodians of property . . . . . . . . . . . . . . 45

57. Custodian of instruments ............... 46

58. Origin of accountability ................. 46

59. Invoices and receipts .................... 46

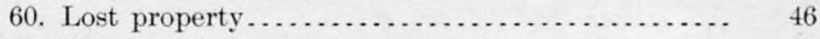

61. Returns of property $\ldots \ldots \ldots \ldots \ldots \ldots \ldots \ldots \ldots \ldots .47$

62. The Survey ration...................... 48

63. Accountability of employees ............... 49

64. Storage and care of animals............... 49

65 . The Survey brand ..................... 50

Bond-aided railroads......................... 50

66. Money payments prohibited $\ldots \ldots \ldots \ldots \ldots \ldots \ldots . \quad 50$

67. Transportation of persons .................. 51

68. Transportation of property $\ldots \ldots \ldots \ldots \ldots \ldots \ldots . \quad 51$ 



\title{
LETTER OF TRANSMITTAL.
}

\author{
Department of the Interior, \\ United States Geological Survey, \\ Washington, D. C., December 20, 1902.
}

SIR: The first edition of the Survey "Regulations" was approved by the Secretary of the Interior on August 16, 1882, to take effect September 1, 1882. That edition having become exhausted, a second edition was approved June 9, 1893, to take effect July 1, 1893. The experience of the last ten years has shown the desirability of a number of modifications in the "Regulations" and the removal therefrom of certain items of a less important and more temporary character, which can better be placed in a series of "Instructions" from the Director. Herewith is submitted, therefore, for your consideration and approval, a draft of revised "Regulations," for the information and guidance of the officers and employees of the Geological Survey, to take effect January 1, 1903.

Very respectfully,

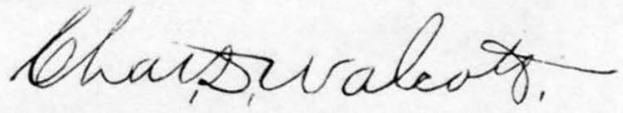

Director.

The Secretary OF the INTERIOR.

Approved December 27, 1902.

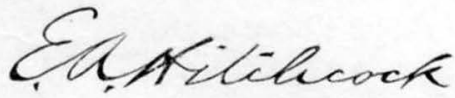

Secretary of the Interior. 


\section{REGULATIONS ·}

OF THE

\section{UNITED STATES GEOLOGICAL SURVEY.}

\section{INTRODUCTION.}

The following regulations have been prepared for the guidance of officers and employees of the United States Geological Survey. They are derived in large part from statute law, from decisions of the accounting officers of the Treasury Department, and from official circulars of the Department of the Interior. It is believed that close adherence to these directions will prove helpful to all members of the Geological Survey. This manual of "Regulations," approved by the Secretary, is intended to cover the more important matters relating to the general administrative work of the Survey. A separate series of "Instructions" is issued by the Director for the guidance of the various field assistants and party chiefs.

\section{ORGANIC AND OTHER LAWS, WITH INSTRUC- TIONS RELATING THERETO.}

\section{The Organic Law.}

1. The United States Geological Survey was organized by an act of Congress approved March 3, 1879. To the paragraph creating the office of Director of the Geological Survey the following proviso was attached:

* * * That this officer shall have the direction of the Geological Survey, and the classification of the public lands and examination of the geological 
structure, mineral resources, and products of the national domain. And that the Director and members of the Geological Survey shall have no personal or private interests in the lands or mineral wealth of the region under survey, and shall execute no surveys or examinations for private parties or corporations. * * * And all collections of rocks, minerals, soils, fossils, and objects of natural history, archæology, and ethnology, made by the Coast and Interior Survey, the Geological Survey, or by any other parties for the Government of the United States, when no longer needed for investigations in progress, shall be deposited in the National Museum. * * *-Stat, L., vol. 20, p. 39/.

2. In the act making appropriations for sundry civil expenses of the Government for the fiscal year ending June 30, 1883, approved August 7, 1882, the Survey was authorized-

* * * to continue the preparation of a geological map of the United States.

* * * And not to exceed ten thousand dollars of the amount appropriated in this paragraph may be applied, under the direction of the secretary of the Interior, to the procuring of statistics in relation to mines and mining other than gold and silver, and in making chemical analysis of iron, coal, and oil.Stat. L., vol. 22, p. 329 .

3. An act approved June 11, 1896, contained the following provision:

* * * That hereafter in such surveys west of the ninety-fifth meridian elevations above a base level located in each area under survey shall be determined and marked on the ground by iron or stone posts or permanent bench marks, at least two such posts or bench marks to be established in each township or equivalent area, except in the forest-clad and mountain areas, where at least one shall be established, and these shall be placed, whenever practicable, near the township corners of the public-land surveys; and in the areas east of the ninety-fifth meridian at least one such post or bench mark shall be similarly established in each area equivalent to the area of a township of the publie-land surveys. *** - Stat. L., vol. 29, p. 435.

\section{Hydrographic and Reclamation Service.}

\section{The following resolution of Congress was approved March 20, 1888:}

That the Secretary of the Interior, by means of the Director of the Geological Survey, be, and he is hereby, directed to make an examination of that portion of the arid regions of the United States where agriculture is carried on by means of irrigation, as to the natural advantages for the storage of water for irrigating purposes, with the practicability of construeting reservoirs, together with the capacity of the streams and the cost of construction and capacity of reservoirs, and such other facts as bear on the question of storage of water for irrigating purposes. *** -Stat. L., vol. 25, p. 619 . 
2. The following provisions were embodied in an act of Congress approved October 2, 1888:

For the purpose of investigating the extent to which the arid region of the United States ean be redeemed by irrigation, and the segregation of the irrigable lands in such arid region, and for the selection of sites for reservoirs and other hydraulic works necessary for the storage and utilization of water for irrigation and the prevention of floods and overflows, and to make the necessary maps, including the pay of employees in field and in office, the cost of all instruments, apparatus, and materials, and all other necessary expenses connected therewith, the work to be performed by the Geological Survey, under the direction of the Secretary of the Interior. *** And all the lands which may hereafter be designated or selected by such United States surveys for sites for reservoirs, ditches, or canals for irrigation purposes * * * are from this time henceforth hereby reserved from sale as the property of the United States, and shall not be subject after the passage of this act to entry, settlement, or occupation until further provided by law. * * * -Stat. L., vol. 25, pp. 526, 527.

3. An act approved August 30, 1890, contained the following provisions:

* * * That reservoir sites heretofore located or selected shall remain segregated and reserved from entry or settlement as provided by said act, until otherwise provided by law, and reservoir sites hereafter located or selected on public lands shall in like manner be reserved from the date of the location or selection thereof. * * * In all patents for lands hereafter taken up under any of the land laws of the United States or on entries or claims validated by this act west of the one hundredth meridian, it shall be expressed that there is reserved from the lands in said patent described, a right of way thereon for ditches and canals constructed by the authority of the United States.-Stat. L., vol. 26, p. 391 .

4. The following provisions are in the reclamation act approved June 17, 1902:

* * * That all moneys received fron the sale and disposal of public lands in Arizona, California, Colorado, Idaho, Kansas, Montana, Nebraska, Nevada, New Mexico, North Dakota, Oklahoma, Oregon, South Dakota, Utah, Washington, and Wyoming, beginning with the fiscal year ending June thirtieth, nineteen hundred and one, including the surplus of fees and commissions in excess of allowances to registers and receivers, and excepting the five per centum of the proceeds of the sales of public lands in the above States set aside by law for educational and other purposes, shall be, and the same are hereby, reserved, set aside, and appropriated as a special fund in the Treasury to be known as the "reclamation fund," to be used in the examination and survey for and the construction and maintenance of irrigation works for the stor- 
age, diversion, and development of waters for the reclamation of arid and and semiarid lands in the said States and Territories, and for the payment of all other expenditures provided for in this act.

* * * That the Secretary of the Interior is hereby authorized and directed to make examinations and surveys for, and to locate and construct, as herein provided, irrigation works for the storage, diversion, and development of waters, including artesian wells. ***

* * * That the Secretary of the Interior shall withdraw from public entry the lands required for any irrigation works contemplated under the provisions of this act, and shall restore to public entry any of the lands so withdrawn when, in his judgment, such lands are not required for the purposes of this act; and the Secretary of the Interior is hereby authorized, at or immediately prior to the time of beginning the surveys for any contemplated irrigation works, to withdraw from entry *** any publie lands believed to be susceptible of irrigation from said works. ***

That upon the determination by the Secretary of the Interior that any irrigation project is practicable, he may cause to be let contracts for the construction of the same, in such portions or sections as it may be practicable to construct and complete as parts of the whole project, providing the necessary funds for such portions or sections are available in the reclamation fund. * * * Provided, That in all construetion work eight hours shall constitute a day's work, and no Mongolian labor shall be employed thereon. * * *

That the Secretary of the Interior is hereby authorized and directed to use the reclamation fund for the operation and maintenance of all reservoirs and irrigation works eonstructed under the provisions of this act.

That where in carrying out the provisions of this act it becomes necessary to acquire rights or property, the Secretary of the Interior is hereby authorized to acquire the same for the United States by purchase or by condemnation under judicial process. *** -Stat. L., vol. 32, pp. s8s-s9o.

\section{The following paragraph appears in an act approved June 28,} 1902:

For gauging the streams and determining the water supply of the United States, and for the investigation of underground currents and artesian wells and the preparation of reports upon the best methods of utilizing water resources. *** -Stat. L., vol. S2, p. 455.

\section{Forest Reserves.}

1. The following provisions were included in an act approved June 4, 1897:

For the survey of the public lands that have been or may hereafter be designated as forest reserves by Executive proclamation, under section twenty-four 
of the act of Congress approved March third, eighteen hundred and ninetyone, entitled "An Act to repeal timber-culture laws, and for other purposes," and including public lands adjacent thereto, which may be designated for survey by the Secretary of the Interior, one hundred and fifty thousand dollars, to be immediately available.

The surveys herein provided for shall be made, under the supervision of the Director of the Geological Survey, by such person or persons as may be employed by or under him for that purpose, and shall be executed under instructions issued by the Secretary of the Interior; and if subdivision surveys shall be found to be necessary, they shall be executed under the rectangular system, as now provided by law. The plats and field notes prepared shall be approved and certified to by the Director of the Geological Survey, and two copies of the field notes shall be returned, one for the files in the United States surveyorgeneral's office of the State in which the reserve is situated, the other in the General Land Office; and twenty photolithographic copies of the plats shall be returned, one copy for the files in the United States surveyor-general's office of the State in which the reserve is situated; the original plat and the other copies shall be filed in the General Land Office, and shall have the facsimile signature of the Director of the Survey attached.

Such surveys, field notes, and plats thus returned shall have the same legal force and effect as heretofore given the surveys, field notes, and plats returned through the surveyors-general; and such surveys, which include subdivision surveys under the rectangular system, shall be approved by the Commissioner of the General Land Office as in other cases, and properly certified copies thereof shall be filed in the respective land offices of the districts in which such lands are situated, as in other cases. All laws inconsistent with the provisions hereof are hereby declared inoperative as respects such surveys: Provided, however, That a copy of every topographic map and other maps showing the distribution of the forests, together with such field notes as may be taken relating thereto, shall be certified thereto by the Director of the Survey and filed in the General Land Office.-Stat. L., vol. $30, p .34$.

\section{In an act approved March 3, 1897, the following was included:}

And provided further, That hereafter all standard, meander, township, and section lines of the public-land surveys shall, as heretofore, be established under the direction and supervision of the Commissioner of the General Land Office, whether the lands to be surveyed are within or without reservations, except that where the exterior boundaries of public forest reservations are required to be coincident with standard, township, or section lines such boundaries may, if not previously established in the ordinary course of the public-land surveys, be established and marked under the supervision of the Director of the United States Geological Survey whenever necessary to complete the survey of such exterior boundaries. * * * -Stat. L., vol. 30, p. 1097 . 


\section{Alaska.}

\section{The following resolution was approved on March 1, 1899:}

* * * That the Director of the Geological Survey is hereby authorized and directed to prepare maps of Alaska showing all known topographic and geologic features, including what is known of the gold-bearing rocks, and a text of the same, the text to contain also an explanation of the best known routes and methods of reaching the gold fields; twenty thousund copies of the maps and text to be printed, five thousand for the use of the Senate, ten thousand for the use of the House of Representatives, and five thousand for distribution by the Geological Survey; and the Director is authorized to have said maps and text prepared and printed in the engraving and printing division of the Geological Survey. * * * -Stat. L., vol. 30, p. 1391.

\section{Publications.}

1. The act establishing the Geological Survey, approved March 3,1879 , contained the following provisions:

The publications of the Geological Survey shall consist of the annual report . of operations, geological and economic maps illustrating the resources and classification of the lands, and reports upon general and economic geology and paleontology, * * * and all literary and eartographic materials received in exchange shall be the property of the United States and form a part of the library of the organization; and the money resulting from the sale of such publications shall be covered into the Treasury of the United States. Stat. L., vol. 20, pp. 394-395.

2. In an act approved August 4,1886 , there is the following provision:

Provided further, That all printing and engraving for the Geological Survey * * * shall hereafter be estimated for separately and in detail, and appropriated for separately. *** -Stat. L., vol. 24, p. 255.

3. A resolution approved February 18, 1897, reads as follows:

* * * That the Director of the Geological Survey be, and is hereby, authorized and directed, on the approval of the Secretary of the Interior, to dispose of the topographic and geologic maps and atlases of the United States, made and published by the Geological Survey, at such prices and under such regulations as may from time to time be fixed by him and approved by the Secretary of the Interior; and that a number of each map or atlas, not exceeding five hundred, shall be distributed gratuitously among foreign governments and Departments of our own Government, to literary and scientific associations, and to such educational institutions or libraries as may be designated by the Director of the Survey and approved by the Secretary of the Interior. 
SEc. 2. That one copy of each map and atlas shall be sent to each Senator and each Representative and Delegate in Congress, if published within his term; and that a second copy shall be placed at the disposal of each Senator, Representative, and Delegate.-Stat. L., vol. 29, p. 701 .

4. On May 16, 1902, the following resolution was approved:

* * * That hereafter the publications of the Geological Survey shall consist of the annual report of the Director, which shall be confined to one volume of royal octavo size; monographs, of quarto size; professional papers, of quarto size; bulletins, of ordinary octavo size; mineral resources, of ordinary octavo size; water-supply and irrigation papers, of ordinary octavo size; and such maps, folios, and atlases as may be required by existing law.

That hereafter the reports of the Geological Survey, except the annual report of the Director, shall be published in editions as recommended in each case by the Director and approved by the Secretary of the Interior, but not to exceed ten thousand copies.

That whenever the edition of any of the reports of the Survey shall have become exhausted, and the demand for it continues, there shall be published, on the requisition of the Secretary of the Interior, as many additional copies of the report as the Director of the Survey shall state will, in his judgment, be necessary to meet the demand.

That the bulletins and professional papers shall be distributed gratuitously, and not sold; and that of the number published one thousand copies shall be delivered to the Senate and two thousand copies shall be delivered to the House of Representatives for distribution.

That the provision of law approved June eleventh, eighteen hundred and ninety-six, restricting the water-supply papers to one hundred pages and to editions of five thousand copies shall be, and hereby is, rescinded.-Stat. L., vol. $32, p, 741$.

\section{Legal Prohibitions.}

1. The attention of all officers and employees of the Survey is called to that provision of the law which prohibits them from having personal or private interest in the lands or mineral wealth of the region under survey, and to that which prohibits the survey or examination of property for private parties or corporations. This legal prohibition applies to all members of the Survey holding appointments from the Secretary of the Interior, whether employed the whole or a part of their time on Survey work, and whether receiving an annual salary or a per diem compensation when actually employed. This law will be rigidly enforced. 


\section{Entry Upon Private Property.}

1. In the conduct of the Survey it will sometimes be necessary to enter upon private or corporate mining property. In such cases the officer or employee will put himself in communication with the owners or proper representatives of the owners of the property and announce that permission to enter is requested in the name of the United States Geological Survey, and that all such observations and surveys are marle wholly in the interest of science and that the results are to be used only in the preparation of official reports and maps to be published by the Geological Survey for the benefit of the public.

2. There is no Federal law authorizing employees of the Geological Survey to enter upon private lands against the wishes of the owner or his representative. At the same time the field work of the Survey can not be earried on without entering upon such lands, and in the experience of the Survey objection to such entry has been rare. Chiefs of parties are advised that they enter upon private lands by courtesy only, and will exercise caution in this matter, obtaining permission in advance in all cases of doubt.

3. The States of New York, Pennsylvania, Ohio, and Maine have enacted the following laws (which may be cited, if necessary) in order that employees of the Geological Survey engaged in making cooperative surveys may enter upon private lands:

For the purpose of making the surveys hereinbefore provided for it shall be lawful for persons employed in making the same to enter upon the lands within the boundaries of this State, but this act shall not be construed as authorizing any unnecessary interference with private rights. (New York, Chapter 257, April 4, 1893; Pennsylvania, act of general assembly No. 78, April 28, 1899; Ohio, senate bill No. 60, general assembly, 1897-98; Maine, act of March 16, 1899, sixty-ninth legislature.)

\section{Preservation of Public Monuments.}

1. In the Indian bill approved June 10, 1896, is the following provision of the general statutes.

provided further, That hereafter it sball be unlawful for any person to destroy, deface, change, or remove to another place any section corner, quar- 
ter-section corner, or meander post on any Government line of survey, or to cut down any witness tree or any tree blazed to mark the line of a Government survey, or to deface, change, or remove any monument or bench mark of any Government survey. That any person who shall offend against any of the provisions of this paragraph shall be deemed guilty of a misdemeanor, and upon conviction thereof in any court shall be fined not exceeding two hundred and fifty dollars or be imprisoned not more than one hundred days. All the fines accruing under this paragraph shall be paid into the Treasury, and the informer in each case of conviction shall be paid the sum of twentyfive dollars.-Stat. L., vol. 29, p. 3/4.

\section{Confidential Information.}

1. Information of a confidential character, such as railroad and mine maps, drill records, etc., is frequently supplied to members of the Survey by private parties and corporations. Such information must be carefully guarded and used only under the conditions stipulated by the persons furnishing it. Whenever desired, a guarantee to this effect will be furnished over the Director's signature.

\section{Expert Testimony.}

1. In case a member of the Geological Survey is called on to give expert testimony in any lawsuit involving questions of geologic fact or scientific opinion relative to a mine or mines examined by him in pursuance of his official duty, he is hereby directed to refuse to give such testimony, or to appear in court, unless, when summoned, he is within the jurisdictional limits of the court and is duly served with a subpœena and tendered statutory fees and expenses.

2. In case such fees and expenses are tendered and subpona served within jurisdictional limit, he will present himself in court, and when called to the stand will ask the presiding judge for permission to make a statement and request. Such permission being granted, he will read to the court the following provision of law forbidding private work to members of the Geological Survey:

And the Director and members of the Geological Survey shall have no personal or private interests in the lands or mineral wealth of the region under survey, and shall execute no surveys or examinations for private parties or corporations.

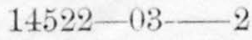


He will also state that a condition of his admission to mines is the avoidance of all private or unofficial use of knowledge so gained. He will further state that the value and effectiveness of the Geological Survey depend in large measure upon the unprejudiced action of the corps and its complete removal from all private interests or contests, and, finally, he will request the presiding judge to excuse him from giving any testimony whatsoever.

3. In the trial of causes the sitting judge is absolute for the time being, but it is confidently expected that upon hearing the above statement he will recognize the propriety of relieving members of the Geological Survey from the duty of testifying.

\section{Private Collections.}

1. As provided by law, all collections made by members of the Survey belong to the Government and must be deposited in the National Museum. Members of the Survey, therefore, can not make collections for themselves or for other persons or institutions.

2. In the case of lithologic collections the material is abundant, and authors may retain working specimens for themselves, provided such collections are made during the progress of their work and in such manner as not to affect the value of the Government collections.

\section{GENERAL INSTRUCTIONS AND OFFICE REG- ULATIONS.}

\section{Organization.}

1. For convenience of administration the Geological Survey is organized in branches, divisions, and sections. The work classifies naturally into five great branches, (1) administrative, (2) publication, (3) geologic, (4) topographic, (5) hydrographic.

2. The branches are subdivided into divisions and the divisions into sections. In the administrative branch the division unit is in most instances an administrative unit. In the technical branches 
the division is in some instances the administrative unit, while in others it is organized for inspection purposes only, and the section is the administrative unit.

\section{Official Correspondence.}

1. All official letters to the office of the Director should be addressed to the Director, United States Geological Survey, Washington, D. C., and should refer to one subject only.

2. Official correspondence may be classified as external and internal. The former will be signed by the Director, or by his instruction. The latter may be direct between chiefs of divisions and parties and their subordinates. Correspondence between different divisions should pass through the Director, and between subordinates and the Director through chiefs of divisions.

3. A Department order reads as follows:

Hereafter chiefs of bureaus and offices, or other officials of this Department, will not communicate with other executive branches of the Government, or with Congress, or committees thereof, upon matters relating to the affairs of said bureaus and offices, except through the office of the Secretary of the Interior.

\section{Use of Official Frank.}

1. Section 5 of an act of Congress approved March 3, 1877, provides-

That it shall be lawful to transmit through the mail, free of postage, any letters, packages, or other matters relating exclusively to the business of the Government of the United States: Provided, That every such letter or package, to entitle it to pass free, shall bear over the words " Official business" an indorsement showing also the name of the Department. ***-Stat. L., vol. 19, pp. s55-336.

2. In interpretation of the above it has been ruled that publications emanating from a bureau may be franked as part of the official response to a communication asking information of the bureau. Such publications may not, however, be franked as official if they contain any written or printed memoranda indicating that they have been sent with the compliments of anyone. 


\section{Chief Clerk.}

1. The chief clerk, in the absence of the Director, shall have charge of the office and sign all official correpondence. He shall sign all circulars and letters to members of the Survey "by order of the Director;" shall sign all requests for stationery and all orders for purchases for office use; shall have charge of exchanges and distribution of publications; shall indorse all requests for publications of the Survey; shall receive, open, and distribute the official mail; shall have control of all express or freight shipments; shall keep a record of all property received and issued, and shall supervise the work of all the other clerks and see that it is faithfully performed.

\section{Chief Disbursing Clerk.}

1. The chief disbursing clerk shall have general charge of the fiscal operations of the Survey, and special disbursing agents shall act under his general instructions. He shall have charge of and shall audit all money accounts; shall make all office payments for services and supplies; shall make out all requisitions for funds; shall keep a record of all accounts with annual appropriations, with disbursing agents, with allotments, and with bonded railroads; shall keep a classified record of expenditures, and shall perform such other duties as are germane to the money responsibility of the Survey.

\section{Librarian.}

1. The librarian is the custodian of the books, maps, and other literary material acquired by purchase, gift, or exchange. He shall keep an account of the contents of the library, of accessions thereto, and of all publications received or withdrawn; shall prepare and maintain a card catalogue of the library, and shall make all purchases of books and maps for the library, except that field parties may purchase local maps, atlases, etc., as needed by them in field work. 
2. In an act of Congress approved June 28, 1902, occurs the following provision:

Provided, That the purchase of professional and scientific books and periodicals needed for statistical purposes hereafter by the scientific divisions of the United States Geological Survey is hereby authorized to be made and paid for out of appropriations made for the said Survey.

3. Purchases for the library shall be limited to publications germane to the work of the Survey.

4. The library shall be accessible to all students who may wish to use it. All books, except works of reference which are in more or less constant use, may be withdrawn for study, but should be returned as soon as practicable, in order that others may not be deprived of their use.

\section{Editor of Publications.}

1. All manuscripts for reports, circulars, etc., shall be transmitted to the Director. Before they are forwarded to the printer they will be submitted to the editor of publications, for his examination and correction.

2. All proofs of such papers, circulars, etc., shall be received, corrected, and returned by the editor of publications.

\section{Illustrations.}

1. All material for illustrations shall be transmitted to the Director. With the exception of topographic and geologic sheets, all such material, before it is forwarded for reproduction, will be submitted to the chief of the section of illustrations, who shall have suitable drawings prepared for publication, shall give directions or write specifications for their reproduction by appropriate processes, shall correct and approve the proofs, and shall have the custody and care of the electrotypes.

\section{Photography.}

1. All cameras and other photographic apparatus used by employees of the Survey may be purchased only on requisitions 
approved by the chief photographer, though they shall be paid for from the separate allotments to the divisions for which they are purchased. Photographic materials must not be used for any purpose other than the procuring of scientific data which will be of use in the Geological Survey.

2. All requisitions for photographs, development of negatives, or printing made upon the photographic laboratory must be on the cards provided for that purpose, and must state clearly the object for which the work is to be used, and such requisitions shall be transmitted through the chief clerk for his approval.

\section{Custodian of Documents.}

1. All books, maps, folios, ete., intended for distribution shall be deposited in the document section and be issued therefrom on approval of the chief clerk.

2. The author of a report, if not a sale publication, shall be entitled to 20 copies, and each author of a map or a folio shall be entitled to 2 copies.

\section{Classification of Technical Force.}

1. There are two classes of employees in the Geological Survey, (a) those holding appointments from the Secretary of the Interior, who may be employed either in the field or in the office, and (b) such field assistants, laborers, etc., as may be necessary in the work of a field party, who are selected by the heads of parties, under the direction of their chiefs, at a per diem or monthly compensation.

2. Employees of the technical force of the Survey holding appointments from the Secretary are grouped into classes-for example, geologist, assistant geologist, and geologic aid-according to the amount of compensation. Persons entering the service are required to have a thorough technical and scientific education, and are appointed by certification from the Civil Service Commission after passing an examination showing their technical knowledge and practical experience. 
3. Promotions are considered by boards composed of the higher officers in each branch, and their findings are transmitted to the Director for his guidance in making recommendations to the Secretary of the Interior. These are based in every case upon the record made by the person concerned-his reputation for accuracy and ability, and particularly the results of his work as shown by completed maps, manuscripts, statements, etc.

\section{Transfers from 0ne Division or Section to Another.}

1. Members of the Geological Survey desiring to be transferred from one division or section to another must apply through their immediate chiefs. The chief of the division or section will make indorsement on the application and forward the same to the Director.

2. The chief of one division or section must not approach a person employed in another division or section in regard to a transfer without first consulting the chief of the other division or section.

3. When persons are transferred from one division or section to another they will not be promoted until they have shown fitness for advancement to a higher grade.

\section{Leaves of Absence.}

1. Leave of absence with pay may be granted for a period not exceeding thirty days in any calendar year. Additional leave with pay not to exceed thirty days may be granted on account of sickness.

2. All leave in excess of the above-named limitations must be for satisfactory reasons and without pay.

3. All applications for leave must be made on forms provided for the purpose and be approved by the division or section chief.

\section{Employment of Field Assistants, Rodmen, Chainmen, Flagmen, and Laborers.}

1. Only graduates of technical schools or those who have had special experience are eligible for employment as field assistants in the Geological Survey. 
2. Persons employed as rodmen, chainmen, and flagmen, or in any capacity, shall be not less than 20 years of age; and if students at school or college, must agree to remain with the Survey until the close of the field season, provided their services are satisfactory.

3. The class of persons grouped under the general term of laborers, including drivers, packers, and cooks, will be employed during the field season by the chiefs of parties as necessity may arise, by the day, week, or month.

4. All the employees above mentioned will, when practicable, be engaged in or near the areas under survey, and they must present themselves at the field outfitting point of the party to which they are attached and will be discharged at the end of the field season. No traveling expenses to the field will be allowed; but, provided the employee remain with the party until the close of the period agreed upon, return traveling expenses will be paid to the place where he was employed, or to his home, if the expense to the latter be less and he presents sworn accounts covering such journey. Preference will be given to applicants from States in which the work is to be done.

\section{Importunities for $\mathrm{P} 1$ smotion.}

1. The following amendment to Civil Service Rule XI was made by the President on July 3, 1902:

No recommendation for the promotion of any employee in the classified service shall be considered by any officer in making promotions except it be made by the officer or officers under whose supervision or control such employee is serving; and such recommendation by any other person, with the knowledge and consent of the employee, shall be sufficient cause for debarring him from the promotion proposed, and a repetition of the offense shall be sufficient cause for removing him from the service.

2. Importunities for promotion are strictly prohibited. Chiefs of divisions and sections are directed to note all violations of the above order coming to their attention. The supervising officers are thoroughly informed and competent to judge of the qualifications of those under their direction, and will endeavor to do justice in all cases. 
3. It is not to be understood that employees are forbidden to appeal to the Secretary on the ground of unjust discrimination against them, or to report unfair or improper treatment. Such appeal, however, must be in writing, must state explicitly some substantial ground of complaint, and must be forwarded through the Director.

\section{Monthly Reports.}

1. It is important that the Director be constantly informed of the progress of the Survey in all its departments in field and office. For this purpose a monthly report is required from the chief of each division or section. The report should be made promptly at the end of the month, and should clearly but briefly exhibit the operations of that month.

2. Chiefs of divisions or sections should require their assistants in charge of parties to submit their monthly reports promptly, that they may be incorporated in the reports to the Director.

\section{Notes and Notebooks.}

1. In taking notes assistants should leave nothing for the memory. Everything should be recorded so fully and systematically as to be readily understood by any person having occasion to use the notes at any time.

2. All notebooks are the property of the Government and must be deposited in its archives.

\section{Requisitions.}

1. Supplies will be issued on requisition by the employee requiring them, the requisition being approved by the chief of division or section and countersigned by the chief elerk. Supplies fall in two groups, the first consisting of those which are not consumed in the using, such as instruments, ink wells, shears, ete, and which are not expendable, and the second consisting of those which are consumed in the using, such as ink, paper, etc., and which are expendable. 


\section{REGULATIONS OF GEOLOGIOAL SURVEY.}

2. The issuing clerk will require receipts for all nonexpendable articles from the persons drawing the articles, who will account for them when required.

\section{Shipment:}

1. The Survey is in almost daily receipt of material by freight and express. To facilitate the prompt and easy assignment of this material to its proper place, officers and employees are enjoined to carefully observe the following directions:

(a) Address all packages to the Director of the United States Geological Survey, Washington, D. C.

(b) Indicate on the label the contents and from whom and from where sent.

(c) At time of shipment always notify the Director, on the form provided for the purpose; of the shipment, its mode, whether by freight or express, and the contents.

2. Printed receipts must accompany vouchers for freight or expressage from incorporated companies. The subvouchers must give date of shipment, shipping point, destination, names of consignee and consignor, weight, rate, amount charged, and condition when received.

\section{Smoking and Use of Matches.}

1. Smoking will not be allowed in the halls of the buildings occupied by the Geological Survey, nor in the rooms occupied by lady employees.

2. The use of parlor matches or any other than safety matches within the buildings of the Geological Survey is strictly prohibited.

\section{DUTIES OF DISBURSING AGENTS.}

\section{Prefatory Statement.}

1. There are numerous laws of the United States regulating the disbursing of money by its agents. All disbursing agents are required to submit their official accounts to the accounting officers of the Treasury, who pass judgment on their legality. The rulings 
of the accounting officers form a body of judicial law supplementary to statute law. The entire system of enactments and rulings is so voluminous and complex that no successful attempt has been made to codify it. There is no comprehensive publication of it, and the disbursing agent ordinarily discovers its restrictions one by one, by unknowingly running counter to them and having his errors detected by the accounting officers. This is especially the case in the Geological Survey, where it is impracticable to send specially trained clerks to all points at which money must be expended, and, as a matter of economy, the work of disbursement is distributed among professional assistants, whose attention is engrossed by other duties. Tc reduce the doubts and errors of these assistants to a minimum, : $z$ endeavor is here made to present, for their guidance, a code of instructions covering the more important points. For the purpose of narrowing the field of these instructions they are more especially addressed to those members of the Survey who are called on to make disbursements at a distance from the central office.

\section{Relation to the Government.}

1. Disbursing agents of the Survey are bonded officers, required to render account of public moneys intrusted to them.

2. The relation of the disbursing agent to the Government differs in an important respect from that of a private business agent to his employer. In the latter case the employer is an individual, having a personal interest in the business transacted and a personal acquaintance with his agent. In the former case the employer is impersonal, and can not directly supervise the transactions of the agent. The disbursing agent is therefore essentially a trustee, and the funds in his charge are trust funds; so that it is not without reason that he is required to submit to a system of restrictive regulations which in ordinary commercial business might be regarded as onerous. The private employer assumes the integrity of his agent until the contrary is proved; the Government requires its agents to establish the integrity of all their transactions. 


\section{Bonds.}

1. Disbursing agents must give bond before they can be recognized as such at the Treasury. Forms for bonds, accompanied by instructions, are prepared by the Department of the Interior, and will be furnished by the Director to members of the Survey who are appointed disbursing agents.

\section{Allotments.}

1. Portions of the funds of the Survey are appropriated by law or allotted by the Director for specified purposes, and are expended under the direction of designated officers.

2. Each disbursing agent will open a ledger account with each specific allotment, crediting it with all sums assigned to it and charging to it all sums disbursed for the specified purpose. He should also charge the allotment with all accounts pertaining to the specified purpose and paid by others or requiring future payment by others. Chief among these are the cost of transportation of persons on official requests and the estimated cost of transportation of freight on bills of lading. The balance of this ledger account will indicate the unexpended portion of the allotment.

3. Against these allotments must be charged all expenditures whatsoever pertaining to the work in the period for which the allotment is made, including salaries of permanent and temporary employees, transportation, expressage, freight, subsistence, and miscellaneous expenses.

4. It is to be understood that the amount allotted will cover all expenses of the work for which it is made, and must under no circumstances be exceeded.

\section{Estimates.}

1. When the disbursing agent has been notified of his allotment he will address a letter to the Director, giving an estimate of the amounts needed by him for a month or other stated period and request that they be placed to his credit. This is done on a printed form prepared for the purpose.

2 . In response to this estimate the Director will ask the Secretary of the Interior to make a requisition upon the Secretary of 
the Treasury, and drafts will be sent to the indicated assistant treasurers and designated depositories. The recipients of the drafts will then notify the disbursing agent that the funds have been placed to his credit.

\section{Treasury Drafts.}

1. It will sometimes occur that the disbursing agent has need to make use of a direct draft on the United States Treasury. He may obtain such draft for public use by applying in person or by letter to the Treasurer of the United States.

\section{Identification.}

1. If the signature of the disbursing agent is not on file with the assistant treasurer or depositary giving him credit, he will need either to present himself with proper introduction and leave his signature, or else send his signature by mail, properly certified by some person whose signature is known. His checks will then be honored to the extent of his credit.

\section{Checks.}

1. Disbursing agents are required to have their funds deposited either with-

(a) The Treasurer of the United States; or

(b) An assistant treasurer of the United States; or

(c) A designated depositary;

and disbursing agents are not responsible for the loss of funds thus deposited.

2. They are also required in most cases to make disbursements by checks, and are thus relieved of the responsibility involved in the actual handling of cash. The Secretary of the Treasury has, however, specifically authorized certain disbursing agents to make payments in cash, by drawing for this purpose, in advance, by checks payable to themselves, a limited amount of money. Up to the present time this autbority has been granted to each disbursing agent of the Geological Survey. It is a specific and not a general authority. It permits the disbursing agent, when the needs of the Survey require, to hold in his personai possession 
public funds to an amount not exceeding the indicated limit, and it relieves him of the necessity of making each payment by means of a separate check.

3. Check books for the use of disbursing agents are issued by the Treasury and subtreasuries of the United States. Instructions for their use are pasted inside the cover of each check book. The stub, when properly filled, constitutes a complete record of the check, and also shows the balance remaining to the credit of the disbursing agent in the depository. It can be used advantageously in making up weekly statements.

4. Each check issued by a disbursing agent must state the object for which the disbursement is made.

5. Checks must not be signed in blank nor antedate the voucher in payment of which they are given.

6. Checks payable to bearer should be avoided.

7. When one check is used to pay two or more vouchers, this fact should be recorded on each voucher by amending its brief to read, "Paid by part of check No. - ," in place of "Paid by check No. - ."

\section{DISBURSEMENTS.}

\section{Classification of Disbursements.}

1. When practicable, disbursements for the Geological Survey are classed under three heads, for which separate blanks are provided, viz:

(a) Services.

(b) Traveling expenses.

(c) Purchases and miscellaneous.

\section{Rendering of Voucher Accounts.}

1. Each employee who has an appointment from the Secretary must submit his own subvoucher accounts, these accounts to be assembled in chronological order on a purchase or traveling-expense voucher. Such accounts must not be submitted more than twice in the same month for the same appropriation, and must include expenditures for one month only, except in case of defective accounts returned by the certifying officer for correction; these 
should be included in the first account submitted after the corrections are made. Traveling-expense accounts for a continuous journey are excepted.

\section{Vouchers in Duplicate.}

1. All vouchers must be written and signed in duplicate. One set is transmitted by the disbursing agent to the Director of the Survey at the end of each month, and is ultimately filed in the archives of the Treasury Department. The other set remains in the hands of the disbursing agent.

2. All vouchers and other money papers must be written in permanent ink. The use of aniline inks and of the "indelible pencil" is prohibited.

\section{Disbursements for Services.}

1. Every permanent employee of the Survey receives a written appointment from the Secretary of the Interior, and payment for services must not precede the date of such appointment.

2. The Treasury Department requires that the appointee shall take the oath of allegiance to the United States, which oath must be attested by a person duly empowered to administer oaths.

3. A new oath must be taken in case of promotion, reappointment, or change of designation.

4. Disbursements for services comprise the payment of salaries or wages, reckoned by the year, month, or day. Permanent employees are generally, though not always, paid an annual salary.

5. Vouchers for services must never include more than one calendar month, though more than one set of vouchers may be submitted in the same month when chargeable against more than one allotment. Two forms of vouchers are used for the payment of salaries, the service voucher for the payment of one person, and the pay roll for the payment of two or more persons.

6. A service voucher consists of a bill, a certificate, and a receipt. The receipt is signed by the person performing the service, and the name at the head of the bill must be literally identical with the name signed to the receipt. 
7. A pay roll consists of a series of receipts and a certificate. The names in the column headed "Names" must be literally identical with those in the column headed "Signatures." In the column "Time employed" must be stated dates from and to and total number of days for fractional parts of a month.

8. In both the above cases the certificate is signed by the person under whose direction the services are performed.

9. In the service voucher the date of the bill is the date of the last day of service. The date of the receipt can not be earlier than the date of the bill, for it is not permitted to make advance payments for services.

10. The number of dollars and cents in the receipts must be legibly written in words, followed by the same amount expressed in figures.

11. In computing the amount of pay due at an annual or monthly rate for a whole or part of a month the Government salary tables must be used. A part of these tables is reprinted in the Survey book of "Instructions."

12. It is desirable that service begun within a month be paid for at the end of the month, and subsequent service date from the first of the following month.

13. For services rendered in two fiscal years separate vouchers are required for each year. The fiscal year begins July 1 and ends June 30 .

14. The use of ditto marks for dates should be avoided.

15. The name of the disbursing agent who furnishes the funds is written in the body of the receipt at the top of the pay roll. The certificate at the bottom of the roll is signed by the officer under whose direction the services were performed.

16. Disbursing officers, before making final settlement with a discharged employee, should be furnished with evidence that he has turned in all Government property in his possession.

17. Temporary field employees may be paid on service vouchers, pay rolls, or, where necessary, subvouchers.

18. When the employee can not write, he must affix his mark, and some person other than the disbursing agent or approving officer must sign as witness. 


\section{Vouchers from Employees.}

1. It is not permitted to purchase or hire property of employees. A man may, however, be hired in connection with his horses, wagons, or other property, the whole being covered under one agreement and accounted for by a single voucher.

2. When the material hired is merely accessory to the services of the employee, as when an artisan is hired with his tools or a surveyor with his instruments, a service voucher should be used. When the services of the person are accessory to the use of the material, as when a driver accompanies a hired team, the voucher is for hire of property, with mention of the personal service and name of the person rendering it, and falls under Schedule K.

\section{Disbursements for Traveling Expenses.}

1. An authorization to make a journey must be signed by the approving officer and accompany each traveling-expense account.

2. The name of the person performing the journey must appear at the head of the voucher. His signature to the certificate must be attested before a notary or other officer empowered to administer oaths and must be duly sealed. The certificate of a postmaster with his dating stamp may be substituted if it is impracticable to obtain the services of an officer authorized to administer oaths for general purposes. This attestation may be waived in exceptional cases when neither of the above-mentioned officers can be reached without undue delay or cost, but in such cases full explanation must be made.

3. Bills will be allowed for actual and necessary expenses of travel, subject to such restrictions as are established by Treasury regulations. These expenses include:

(a) Fares upon railroads, steamboats, packets, or other usual modes of conveyance.

(b) Hire of special transportation, either by land or by water, when there are no regular means of conveyance.

(c) Ferriage, tolls, and horse keeping.

$$
14522-03-3
$$


(d) Street car or omnibus or transfer-coach fare, and, when there are no such conveyances, moderate and necessary hack hire not exceeding the legal rates; also baggage fees to porters.

(e) Sleeping-car fare for one double berth for each person, parlorcar seat (for distances exceeding 100 miles), or customary stateroom accommodation on boats, steamers, ete. Porterage on sleeping cars or boats, not to exceed 25 cents a day (of twenty-four hours).

(f) Lodging and meals en route.

(g) Hotel expenses, not exceeding $\$ 5$ a day, when the detention is incident to or necessary for the performance of the duties for which the travel is ordered. Hotel bills must show the number of days charged for, the regular per diem rate for board and lodging, together with the dates when the same were furnished.

(h) Necessary meals en route, but for no other items of refreshment than the ordinary food provided for travelers. No charge will be allowed for hotel bills when the detention is unnecessary for the execution of the orders under which the journey is performed, nor for meals furnished on steamers or other means of conveyance which are included in the charge for fare.

(i) Extra fare for travel on limited trains will not be allowed.

(j) Charges for telegrams must be accompanied by copies of the messages. Only Government rates will be allowed.

$(k)$. Charges for telephone service must contain a statement of places to and from, and the time occupied.

(l) Subvouchers, properly receipted, will in all cases be required for any kind of livery hire, feed or stabling of horses, services or board of drivers or guides, express, telegraph, or telephone messages, or for any miscellaneous expenditure where the total sum amounts to $\$ 1$ or more. Charges for laundry work or for baths will not be allowed.

$(m)$ Every officer or other person traveling as above indicated will keep a memorandum of the expenditures herein allowed, noting each item as soon as the expenditure is made, and will make affidavit that the different charges in detail therein have been taken from and verified by his memorandum; that they are correct and just; that the amount charged was actually 
paid; that no part of the journey charged for has been made under a free pass on any railway, steamboat, or other public conveyance; that the number of days for which the same is charged were necessarily consumed in unavoidable delays incident to travel and in the performance of the duty ordered or service rendered, and that the journey was performed with all practicable dispatch by the usually traveled routes, under orders (copy annexed), or for the purpose of (here the object of the journey should be fully stated).

4. The notarial or jurat fee paid should be charged as the last item on a traveling-expense account, but need not be dated. No such fee will be allowed unless claimed in the account to which it pertains. It must not exceed the legal rate.in the State or Territory where taken, and must be administered by a notary or some other officer authorized to administer oaths and having a seal.

5. It has been ruled by the Treasury Department that the traveling-expense vouchers, though required to be made in duplicate, constitute in fact but one account, and but one notarial fee will be allowed.

6. Payment of fare to bond-aided railroads or their leased or operated lines is forbidden by law. In traveling by such roads it is necessary to use transportation requests signed by the Director. (See page 51, section 67.)

\section{Fiscal Years and Quarters.}

1 The fiscal year of the Government begins on July 1 and ends on June 30. It is divided into quarters, July, August, and September constituting the first quarter, the next three months the second quarter, and so on. The appropriation for each fiscal year is limited to the work of that year, and therefore no voucher should involve payments belonging to the work of more than one fisca! year.

2 . When a contract for the delivery of property fails to be fulfilled in the fiscal year in which it is made, but is fulfilled in the 
next, payment should be made from the appropriation for the former fiscal year, and a copy of the contract, if written, should accompany the voucher. If, however, the contract is oral, it is sufficient to state that fact in the bill. For example, a bill for a desk ordered in June and delivered in July may read: "For one desk (as per oral agreement June 1, 1892), \$15."

\section{Disbursements for Purchases and Miscellaneous Expenses.}

1. Under this head are embraced all expenditures whateverexcept those for annual and monthly services and traveling expenses. They include the disbursements for purchases, rent, storage, freight, expressage, services by the day or job, contract work, telegraph and telephone charges, and all unclassified expenditures.

2. Two kinds of vouchers are used for these expendituresthe main or purchase voucher and the subvoucher. Each consists of a bill and a receipt, and on the main voucher there are, in addition, a certificate and a custodian's certificate.

3. In the body of the receipt of a main or direct purchase voucher is written or printed the name of the person who pays the account. The certificate is signed by the person who actually makes the purchase. The custodian's receipt is signed by the custodian, who thereby becomes responsible for the property purchased.

4. The name at the head of the bill must be literally identical with the name signed to the receipt. G.W. Armstrong and George W. Armstrong are not identical. Exception is made only when the receipt is signed by the authorized agent of a corporation. A receipt from the Western Union Telegraph Company may be signed by John Day, Operator, or by Joseph Smith, Manager, and in that case the name of the company is written at the head of the bill. The signature Western Union Telegraph Co. is not admissible. A receipt from the Manti Cooperative Store may be signed by the manager or agent, with the name of the corporation at the head of the bill. But from a business firm, only the firm signature can be received. The signature John Smith, by John Doe, or John Smith, per D., or Mrs. Smith, is not admissible. 
5. In taking a receipt from a person who can not write, write his name and have him affix his mark, and then let a disinterested person sign as witness.

6. Each item of purchase must show the number of units, the kind of unit, and the price or rate per unit, as well as the total cost. Thus it would be inadmissible to write merely "hay, $\$ 7$, ," but it is necessary to state the weight and the price per unit of weight. If, however, a piece of work is done as a "job," it is sufficient to state that fact.

7. In filling the receipt to subvouchers there should be written after the word "at" the name of the place where the payment is made, including the State or Territory. If the payment is not made in a town the name of the nearest town should be written. The dollars and cents must be expressed in the receipt in words, and must agree in amount with the total indicated by the bill.

8. Whenever the amount of the payment depends upon a period of time, as in the case of subsistence or forage by the day, storage, rent of buildings or material, etc., the limiting dates must be included.

\section{Telegrams.}

1. The telegraph will be used only when its use will avoid delay which would be prejudicial to the public interest.

2. Care should be taken to use as few words as possible consistent with clearness.

3. The proper charge for an official telegram has changed from time to time, has been a source of uncertainty and resulting annoyance, and has given rise to litigation between the telegraph companies and the United States. By law and the consent of nearly 100 telegraph companies, the rates properly chargeable by these companies are fixed annually by the Postmaster-General.

4. Section 5266 of the Revised Statutes of the United States provides that--

Telegrams between the several departments of the Government and their officers and agents, in their transmission over the lines of any telegraph company to which has been given the right of way, timber, or station lands from the public domain shall have priority over all other business, at such rates as the Postmaster-General shall annually fix. 
5. Pursuant to the authority vested in the Postmaster-General by the act of Congress entitled "An act to aid in the construction of telegraph lines, and to secure to the Government the use of the same for postal, military, and other purposes," approved July 24, 1866, and by the Revised Statutes of the United States, Title LXV, the rates at which such communications as the said statutes prescribe shall be sent by the several companies within the effect of said statutes are fixed as follows for the fiscal year beginning July 1, 1902, and terminating June 30, 1903 :

6. For day messages containing not more than twenty words, exclusive of place from and date, twenty (20) cents, not exceeding one thousand (1,000) miles, and one cent for each additional word, one quarter of this rate to be added for each five hundred (500) miles or fraction thereof, but no rate on a message of twenty (20) words to be more than forty (40) cents, nor on an additional word more than two (2) cents. The rate between all points in any State, Territory, or the District of Columbia shall be twenty (20) cents for twenty (20) words, and one cent for each additional word. In cases where the price of a message, determined as herein provided, includes a fraction of a cent, such fraction, if less than one-half, is to be disregarded; if one-half or more, it is be to counted as one cent. For night messages not exceeding twenty (20) words, exclusive of place from and date, fifteen (15) cents for any distance within two thousand $(2,000)$ miles, and for greater distances twenty-five (25) cents; in each case one cent for each additional word.

7. Instead of computing the actual distances of transmission, the distance for payment shall in all cases be taken absolutely to be the number of miles between the capital of the State or Territory, or from the city of Washington, if from within the District of Columbia, from within which (whatever the place) the message is sent, and the capital of the State or Territory, or the city of Washington, if within the District of Columbia, within which (whatever the place) the message is received, as shown in the book of " $\mathrm{Ir}$ structions," wherein such distances are given as computed upon the shortest practicable route between such capitals, and which is to be taken as part of the order of the Postmaster-General. 
8. The statutes provide that telegrams between the several Departments of the Government and their officers and agents, in their transmission over the lines of any such company, shall have priority over all other business. All officers of the United States sending such telegrams should indorse thereon the words "Official business," and should report to the Postmaster-General any failure to transmit them in such priority, and any charge made in excess of the rates above prescribed.

9. Each company will be allowed to charge for messages received from another line at the same rate as if received from the Government direct at the point of transfer for transmission over its own line.

\section{Explanations.}

1. The approving officer should scrutinize his vouchers to assure himself that they so describe each transaction that it will be readily understood by those whose duty it is to audit it at the central office of the Survey and at the Treasury. If any voucher involves items of expenditure which do not prima facie appear germane to the work, or if any voucher is irregular in point of form, he should explain the circumstances, either by a note attached to the voucher or, preferably, by a memorandum written in red ink upon the face of the voucher. When items are not understood by the auditing officers it is their practice to ask explanation, and it is in every way desirable that all necessary information should be given in advance.

2. It is not proper to add to the substance of a receipt after it has been signed, but interlineations in red ink are understood to be explanatory merely, and are admissible.

\section{Settlement of Accounts by Mail.}

1. It is the universal custom of the Government in the settlement of its bills to require the signing of receipts before payment, and a failure to follow this custom will sometimes lead to serious embarrassment. When accounts are settled by mail, vouchers in duplicate, properly filled, are transmitted to the creditor for signature, and upon their return a check is sent in payment. 


\section{Rent and Storage.}

1. Offices must not be rented without the authority of the Secretary, and specific authority and instructions are necessary for their leasing.

2. Office rent and storage can not be paid in advance, but prepayment of post-office-box rent is authorized by statute.

\section{Oontracts.}

1. The statute regulations affecting contracts on behalf of the Government are so voluminous that no attempt is here made to quote them. Written contracts on behalf of the Survey will not be made without specific authority and instructions from the Director.

2. It is especially to be observed that no officer of the Government can contract for the use of public funds in advance of their appropriation by Congress. Section 3679 of the Revised Statutes reads:

No Department of the Government shall expend, in any one fiscal year, any sum in excess of appropriations made by Congress for that fiscal year, or involve the Government in any contract for the future payment of money in excess of such appropriations.

\section{PROPERTY.}

\section{Classification of Expenditures.}

1. In order that a detailed exhibit may be presented of the manner in which funds appropriated for the Geological Survey are expended for any year or other period of time, the following classification of expenditures is adopted. This classification will afford useful guidance in rendering property accounts, as will appear in subsequent pages.

2. Every expenditure of the Survey must be classed with some one of the following schedules, but it is not assumed that the particulars here enumerated include every item that will arise. Disbursing agents will have to be guided by definitions and analogies in classifying expenditures not specifically named.

3. Expenditures by the Survey are classified in eighteen schedules. These are divided into two groups, the first consisting of those by which property is acquired, the second of those by which property is not acquired. 


\section{Nonexpendable Property.}

1. Any article which endures in service or w'aich when applied to use does not become part of another article otherwise accounted for shall be classed as nonexpendable.

2. Schedule A includes field material, such as the following:

Alforjas.

Animals (horses, mules).

Aparejos.

Apparatus, flash-light.

Awls.

Axes.

Bags, leather collecting, saddle, etc.

Balances, spring.

Basins.

Beaters, egg.

Bells, stock.

Belts, ammunition.

Bits, auger.

Blankets, saddle, horse, pack.

Blowpipes.

Boards, wash, drawing, etc.

Boilers.

Bowls.

Boxes, cash, lunch, mess, photographic negative, etc.

Braces.

Branding irons.

Bridles.

Broilers.

Buckets (pails).

Canoes.

Cans, oil.

Canteens.

Carving sets.

Cases, drawing boards, leather map, notebook, etc.

Cellars, salt.

Chairs, camp.

Chisels.

Cleavers.

Clinch cutters.

Clinching irons.

Clippers.
Clocks, alarm.

Cloths, table.

Coffee mills.

Colanders.

Combs, curry.

Cots.

Covers, pack.

Cups, tea, coffee, etc.

Dippers.

Dishes.

Files.

Filters.

Flags.

Flies, tent.

Floors, tent.

Forks, table, basting, etc.

Funnels.

Gauges, knife.

Gauges, wire.

Graters.

Grates.

Guns.

Halters.

Hammers.

Hammers, shoeing.

Harness.

Hatchets.

Hopples.

Irons, climbing.

Jacks, wagon.

Jars.

Jugs.

Kettles.

Knives.

Knives, shoeing.

Lamps.

Lanterns.

Lap robes. 
Mattocks.

Mortar and pestle.

Oilstones.

Openers, can.

Oven, Dutch.

Pails.

Pans, fry, bread, dish, stew, etc.

Picks.

Pincers.

Pins, picket.

Pitchers.

Planes.

Plates.

Pliers, cutting.

Poles, tent.

Pots, coffee, tea, etc.

Pulleys.

Punches.

Rakes.

Rasps.

Reflectors.

Riveting sets.

Saddles, pack, riding

Saucers.

Saws.

Scales.

Screw-drivers.

Scythes.
Shakers, salt.

Shovels.

Sieves.

Skillets.

slickers.

Soldering outfit.

Spades.

Spoons, basting, table, tea, etc.

Spurs.

Stamps, rubber.

Steamers, cooking.

Steelyards.

Stencil plates.

Stools, camp.

Stoves.

Tables.

Tapelines.

Tents.

Tools.

Tubs.

Tumblers.

Turners, cake.

Vises.

Wagons, road (buckboards, earts, etc.).

Washboards.

Wire cutters.

Wrenches.

3. Schedule B includes instruments used in field and in office, such as the following:

Alidades, telescopic and sight.

Alt-azimuths.

Anemometers.

Barometers, aneroid and mercurial.

Base apparatus.

Cameras lucida.

Chains.

Chronographs.

Chronometers.

Clinometers.

Compasses, beam, box, clinometer, dial, dip, prismatic, ete.

Curves.

Dividers, plain, proportional, spring, etc.
Glasses, field and reading.

Gradienters.

Heliotropes.

Horizons, artificial.

Instruments, drawing.

Lenses, camera, magnifying, etc.

Levels, engineers', hand, circular, ete.

Machines, computing.

Meters, current.

Micrometers.

Microscopes.

Nilometers.

Odometers.

Pantographs.

Pedometers. 
Pens, bow, ruling, ete.

Pins, tally.

Plane-table boards.

Plane-table movements.

Planimeters.

Protractors.

Psychrometers.

Range finders.

Recorders or registers.

Rods, feveling, stadia, transit, ete.

Rules, slide.

Rulers, parallel.

Scales, graduated, triangular, etc.

Section liners.
Sextants.

Sounders.

Spectroseopes.

Splines.

Squares, $T$.

Straightedges.

Switch boards.

Tapes, cloth, metallic, steel, etc.

Telescopes.

Theodolites.

Thermometers.

Transits, astronomic and engineers?

Triangles.

Watches.

4. Schedule $\mathrm{C}$ includes all office furniture and movable wall, floor, or window fixtures.

5. Schedule D includes all books, maps, and pamphlets.

6. Schedule E includes all drawing instruments for field or office use.

7. Schedule $\mathrm{F}$ includes all apparatus and material necessary for photography which comes within the general definition of nonexpendable property.

8. Schedule $\mathrm{G}$ includes all fixtures, instruments, and apparatus necessary for chemical analyses and physical examination of minerals and rocks.

9. Schedule $H$ includes all apparatus, tools, machines, and fixtures needful for engraving topographic and geologic maps and texts.

\section{Expendable Property.}

1. Any article which is perishable or which, when applied to official use, is consumed or is made an essential part of an article otherwise accounted for shall be classed as expendable.

2. Schedule I includes general supplies and repairs, such as the following:

Acid, hydrochloric.

Alcohol.

Ammunition.

Apron, wagon.

Bags, paper, jute, cotton.

Bits, bridle.
Blocks, neck.

Bolts, iron, copper.

Borax.

Bottles.

Bows, wagon.

Boxes, packing. 


\section{Brooms.}

Brushes.

Buckles.

Buckskin.

Burlaps.

Burners, lamp.

Cable, wire.

Candles.

Canvas.

Cement.

Chains.

Chimneys, lamp, lantern.

Cinches, pack, saddle.

Clasps, iron.

Cloth, oil, signal, table, tracing, etc.

Cord.

Collars horse.

Covers, wagon.

Crash, kitehen.

Cushions, wagon.

Duck, tent.

Engraving supplies.

Forage (hay, grain, etc.).

Fuel.

Girths, saddle.

Globes, lantern.

Glue.

Grease, axle.

Hames.

Handles, ax, hammer.

Hasp and staple.

Hinges.

Hooks.

Iodoform.

Iron (for repairs).

Laboratory supplies.

Laces.

Lampblack.

Lash, whip.

Latigos.

Lead.

Leather.

Lifters, stove.

Lines, harness

Lumber.

Lye.

\section{Maps.}

Matehes.

Medicine.

Mops.

Nails.

Needles, harness.

Oil, coal, harness, wagon.

Pads, collar.

Paint.

Paper, tracing, wrapping, etc.

Pearline.

Photographic supplies.

Pipe, stove.

Posts, bench-mark.

Powder, blasting.

Pumice.

Rings.

Rivets.

Rope.

Sacks, grain, specimen, etc.

Salt, stock, table.

Sapolio.

Screws.

Shoes, horse.

Snaps, harness.

Soap.

Soda, washing.

Solder.

Spikes.

Sponges.

Spreaders.

Staples.

Stationery.

Stays.

Steel (for repairs).

Stirrups.

Straps.

Subsistence (ration list, Schedule J).

surcingles.

Tablets, bench-mark.

Tacks.

Tags.

Thread.

Tin.

Towels, dish.

Traces. 
Turpentine.

Twine.

Washers, wagon.

Wax.
Whips.

Wicks.

Wire.

Yoke, breast.

3. Schedule J. Subsistence; ration list (see page 48).

4. Schedule K. Services.

5. Schedule L. Traveling expenses, including expenditures by members or employees traveling under specific instructions.

6. Schedule M. Transportation, including expenditure of transportation of men or property by contract, drayage, express, freight, etc.

7. Schedule N. Illustrations for reports.

8. Schedule O. Office rent.

9. Schedule P. Storage and pasturage.

10. Schedule Q. Correspondence, including post-office box rent, telegrams, rent or use of telephones, etc.

11. Schedule R. Bonded railways, including transportation of messages, persons, or property over the same.

\section{Custodians of Property.}

1. Custodians of property are persons designated by the Director to have charge of and be responsible for public property. Such property is issued to employees of the Survey for public use, and they account for the same on signed inventories transmitted to the custodian. The recipient of the property thus becomes responsible for it until it is returned to the custodian.

2. Custodians of property are required to carry upon their property returns all nonexpendable articles according to the present method of itemized statements, and reference must be made to the vouchers by which such property was acquired.

3. Expendable property will not be carried upon the property returns of custodians. Officers purchasing expendable property in the field will, however, be responsible therefor to the custodian of property for the appropriate division or section, and the purchasing officers shall at the close of each field season, or at least once in six months, make certificates to the effect that the expend- 
able property acquired by vouchers for a stated period has been properly expended for official use or is available and stored under stated conditions. Printed forms of property returns are provided for the quarterly rendering of such statements.

\section{Oustodian of Instruments.}

1. All instruments for field and office use are in the custody of a custodian of instruments, who issues them to the employees of the Survey, taking receipts therefor. All instruments purchased must be transferred to his custody. He is required to keep an account of all instruments in his possession.

2. Instruments not in continuous use, year after year, must be returned to the custodian.

\section{Origin of Accountability.}

1. The certificate of a custodian of property is required upon each purchase voucher, and by signing this certificate he becomes responsible for the property acquired by the purchase. All accountability for property purchased by the survey originates in this way, and in this way each article purchased becomes chargeable to some custodian. The custodian is also accountable for property obtained by requisition from the Department of the Interior.

\section{Invoices and Receipts.}

1. Whenever Survey property is transferred from the charge of one custodian to another the transfer is recorded by means of invoices and receipts. The custodian parting with the property signs an invoice, in duplicate, and gives it to the custodian receiving the property. The receiving custodian gives in return a receipt in duplicate, signed by himself.

\section{Lost Property.}

1. In the conduct of field operations it sometimes occurs that property is lost or destroyed under circumstances not involving negligence on the part either of the employee or of the custodian. 
It is proper that in such cases the custodian should be relieved of accountability. But it is required that affidavit be made to the circumstances. For this purpose a blank is provided, of which the following is an example:

United States Geological Survey,

Oswego, Kans., April 26, 1892.

Personally appeared before me, the undersigned, a notary public within and for Labette County, Kans., John Doe, who deposes and says that on the S1st day of March, 1892, one horse, the property of the United States Geological Survey, was killed, under the following circumstances: The horse was found in his stall with one leg broken and was killed, the injury being of such a nature as to render him unfit for further service.

And he further deposes and says that said accident was not the result of carelessness, neglect, or disobedience of orders, and that no blame can be attached either to Richard Roe, custodian, who is responsible for said property, or to any person in whose charge the above horse was at the time said accident occurred.

Sworn to and subscribed on this 26 th day of April, 1892.

JOHN DOE.

In testimony whereof I have hereunto set my hand.

E. D. KINNEY, Notary Public.

2. When public property has been lost or stolen, without negligence on the part of the user, reasonable charges for the recovery of such property are allowable.

\section{Returns of Property.}

1. Each custodian is required to make a quarterly report of the property for which he is accountable. This report is called a "return of property," and it is essentially a ledger account with egch kind of property in his custody. A printed form is prepared for this purpose.

2. Property is acquired by purchase and by transfer. It is parted with by transfer, by expenditure, by loss certified by affidavit, and by authority of the Director to sell at auction or drop, for all of which special forms are provided.

3. Public property must not be sold, except at public auction with the written authority of the Director.

4. When articles classed as nonexpendable have by use become so worn or injured as to be unserviceable, authority may be 
granted to sell or drop them. Each custodian should submit to the Director, from time to time, upon an inspection report, a list of the unserviceable articles in his hands, and the Director will, if he deems it proper, authorize them to be dropped from the return of property or sold at public auction. Such authorizations, or copies thereof, are filed with the return of property.

5. It sometimes occurs that the property in the hands of a custodian is neither increased nor diminished during an entire quarter. In such case he is not required to prepare a formal return of property, but should transmit to the Director a letter stating the fact, to be filed with his property returns, in order that the history of his accountability may be kept complete.

\section{The Survey Ration.}

1. A ration is the food estimated to be necessary to subsist one man one day. To facilitate the field work of the Geological Survey its parties in camp may purchase at the expense of the Geological Survey the rations described below. The amounts of the various articles in the ration are designed to be sufficiently liberal for all circumstances and must not be exceeded. This ration allowance is neither an emolument nor a perquisite, but is a provision for facilitating the field work of camping parties.

2. The Survey ration is made up of the following articles and amounts:

Schedule J.-Ration list.

\begin{tabular}{|c|c|c|c|c|}
\hline No. & Article. & Unit. & $\begin{array}{l}100 \\
\text { rations. }\end{array}$ & $\begin{array}{l}200 \\
\text { rations. }\end{array}$ \\
\hline 1 & $\begin{array}{l}\text { Fresh meat, including fish, poultry, and } \\
\text { eggs } a \ldots \ldots \ldots \ldots \ldots \ldots \ldots \ldots \ldots \ldots\end{array}$ & Pounds... & 100 & 200 \\
\hline 2 & Cured meat, canned meat, or cheese $b$...... & .... do .... & 50 & 100 \\
\hline 3 & Lard $\ldots \ldots \ldots \ldots \ldots \ldots \ldots \ldots \ldots \ldots \ldots \ldots \ldots \ldots \ldots \ldots$ & ..... do .... & 15 & 30 \\
\hline$\frac{4}{5}$ & $\begin{array}{l}\text { Flour, bread, or crackers..................... } \\
\text { Cornmeal, cereals, macaroni, sago, or corn- }\end{array}$ & do.... & 80 & 160 \\
\hline & 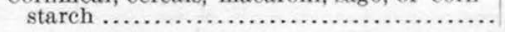 & ...do. & 15 & 30 \\
\hline
\end{tabular}

$a$ Eggs may be substituted for fresh meat in the ratio of 8 eggs for 1 pound of meat.

$b$ Fresh meat and cured meat may be interchanged on the basis of 5 pounds of fresh for 2 pounds of cured. 
Schedule J.-Ration list-Continued.

\begin{tabular}{|c|c|c|c|c|}
\hline No. & Article. & Unit. & $\begin{array}{c}100 \\
\text { rations. }\end{array}$ & $\begin{array}{c}200 \\
\text { rations. }\end{array}$ \\
\hline 6 & 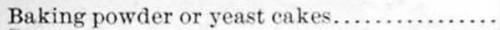 & Pounds ... & 5 & 10 \\
\hline 7 & 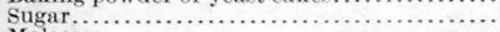 & $\ldots$ do $\ldots$ & 40 & 80 \\
\hline 8 & ................. & Gallons... & 1 & \\
\hline 9 & Coffee... & Pounds... & 12 & 24 \\
\hline 10 & 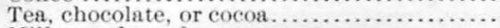 & .... do .... & 2 & \\
\hline 11 & Milk, condensed $a \ldots \ldots \ldots \ldots \ldots \ldots \ldots \ldots \ldots \ldots$ & Cans....... & 10 & 20 \\
\hline 12 & 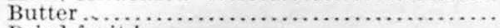 & Pounds... & 10 & 20 \\
\hline 13 & 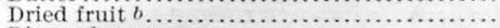 & ..... do .... & 20 & 40 \\
\hline 14 & Rice or beans. $\ldots \ldots \ldots \ldots \ldots \ldots \ldots \ldots \ldots \ldots$ & ..... do .... & 20 & 40 \\
\hline 15 & Potatoes or other fresh vegetables $c$.............. & ..... do .... & 100 & 200 \\
\hline 16 & Canned vegetables or fruit .................. & Cans.. & 30 & 60 \\
\hline 17 & 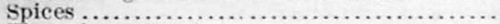 & Ounces... & 4 & \\
\hline 18 & 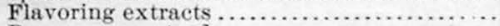 & ..... do ..... & $i$ & \\
\hline 19 & 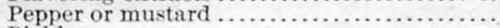 & ..... do .... & 8 & 1 \\
\hline 20 & 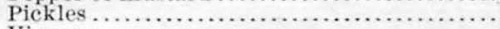 & Quarts. & 3 & \\
\hline 21 & Vinegar ........ & .... do .... & 1 & \\
\hline 22 & 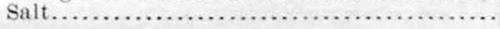 & Pounds... & 4 & \\
\hline
\end{tabular}

$a$ Fresh milk may be substituted for condensed milk in the ratio of 5 quarts of fresh for 1 ean of condensed.

$b$ Fresh fruit may be substituted for dried fruit in the ratio of 5 pounds of fresh for 1 pound of dried.

$c$ Dried vegetables may be substituted for fresh vegetables in the ratio of 3 pounds of fresh for 1 pound of dried.

\section{Accountability of Employees.}

1. Custodians intrusting property to employees will hold them strictly accountable for it. In case of loss or injury to property through neglect they will insist on restitution, by having the lost or injured article replaced or repaired. A fine of the money value is not admissible.

\section{Storage and care of animals.}

1. Field material will, as a rule, be stored during periods of disuse in branch offices or at other convenient points near the fields of work. Receipts must be taken for all material put in storage. Similar regulations hold respecting Survey animals during periods of disuse. Suitable forms of agreement are provided for this purpose.

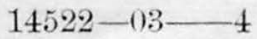




\section{The Survey Brand.}

1. All Survey animals should be hoof-branded with the letters "U. S." and a recorded number, in addition to which the use of the body brand may be continued. Similarly all Survey property should be marked "U.S. G. S."

\section{BOND-AIDED RAILROADS.}

\section{Money Payments Prohibited.}

1. There are certain railroad companies which are indebted to the Government and which are required by law to transport the employees, property, and telegrams of the Government without receiving direct money payments. The value of the transportation furnished is eredited to them, in whole or in part, upon account. In dealing with these roads, which are ordinarily called "bonded" roads, the Geological Survey is not permitted to pay them for services rendered, but is required to certify to the rendering of the services, and is ultimately called upon to make settlement therefor at the Treasury Department.

2. Each account for transportation is ultimately subtracted from the appropriation for the Geological Survey, and each account is chargeable to some allotment. In order, therefore, that the appropriation shall not be overdrawn and a deficiency incurred, it is essential that each transportation account be charged, by the disbursing agent under whose purview it falls, to the allotment to which it properly pertains. In the case of transportation of persons the exact amount of the account can be ascertained at the time the transportation is furnished. In the case of freight it is usually necessary to make an estimate.

3. The following is a complete list of bond-aided railroads:

Central Pacific Railroad (operated by Southern Pacific Company)-

From Ogden Station, Ogden, Utah, to Sacramento, Cal...........

Miles.

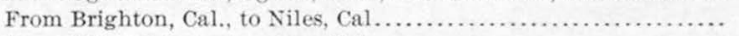

From Niles, Cal., to San Jose, Cal .........................

Missouri Pacifie Railway Company (Central Branch Railway Company)-

From Atchison, Kans., to Waterville, Kans. 
4. Over land-grant roads (see page 52, par. 3) payment may be made for persons; for freight half-rates are permitted, but it is better to make no cash payment.

\section{Transportation of Persons.}

1. Members and employees of the Geological Survey traveling under official orders obtain transportation over bond-aided railroads by presenting transportation requests, which accomplish the double purpose of authorizing and requiring the railroads to furnish the transportation and of certifying that the transportation has been furnished.

2. These requests, signed in blank by the Director, are issued to those officers of the Survey who are authorized in the prosecution of field work to transport their employees. They are bound in series of ten, and each of the books thus formed is accompanied by instructions for its use.

3. A separate request is necessary for each bond-aided road in the line of the journey.

4. The person transported fills out and signs the certificate below the request. When he is accompanied by others, their names should be given. It is customary to present requests to ticket agents and receive tickets in exchange, but under some circumstances they may be presented to conductors.

\section{Transportation of Property.}

1. In the transportation of persons payment is usually made in cash for all parts of the journey which are not upon bond-aided railroads, but in the transportation of property by freight this is impracticable. Whenever any part of the route to be traversed by property is over a bond-aided or land-grant railroad, the charges for the entire distance are made a matter of account. The business is somewhat complicated, and as a means of simplification special bills of lading in duplicate are provided and the form and directions on these show the mode of procedure.

2. Employees of the Survey who have shipments of freight to make over bond-aided or land-grant railroads, or who desire to 
use the Survey bills of lading in shipping over other roads, should, as far as practicable, communicate with their administrative chiefs, to the end that the shipment may be arranged through them, thus insuring the proper procedure.

3. In making such shipments Survey employees, are directed to consult carefully the "Regulations Governing Military Transportation over Land-Grant and Bonded Railroads," with copies of which they will be provided. This contains a full list of such railroads, and especial care must be exercised not to make cash payment for freight shipments over bond-aided or land-grant railroads.

4. To avoid, so far as practicable, the complications incident to such shipments, they may, whenever convenient, be made on requisition through the Quartermaster's Department of the Army.

5. In preparing freight for shipment it should be securely packed, and each package should be marked with its address. The address on boxes should be marked in paint or ink directly on the cover, in addition to being written on a card specially provided for the purpose. Besides the address there should be written the words "Public property."

6. Considerable delay and inconvenience are sometimes occasioned by this procedure, and the assistants of the Survey should bear in mind that these may be avoided if goods are sent by express instead of by freight. The judgment of the assistant will need to be exercised in each individual case to determine which method of shipping is the more economical for the Government.

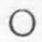



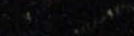